\title{
The Existence and the Construction of 'IIm al-Kalam as Islamic Discipline and Its Significance to Wasatiyyah
}

\author{
FUAD MAHBUB SIRAJ*, RIDWAN ARIF \& EFENDI ${ }^{1}$
}

\begin{abstract}
'Ilm al-kalam or in short the kalam focuses on the fundamental aspects in Islam. This science is important, and it should be used as a guideline in conducting Islamic studies. Essentially, the kalam offers the metaphysical and theological realm, the transcendental domain and future direction; its openness and rational thinking characteristics are necessary and useful for humans; it is not a very rigid discipline of a theoretical science. We need the adamant efforts and the courage to rethink and reconstruct the heritage endowed to us by the scholars of kalam in the past. In other words, it is probably necessary to make a new "ijtihad" because after all the "ijtihad" of the scholars in the past is still considered until now as a good standard in the tradition of Islamic thought. The need for the new ijtihad is due to the new ideologies and approaches associated or linked with Islam and Islamic missionary plans, organizations and activities involving Muslims as well as non-Muslims in the 21st century.
\end{abstract}

Keywords: 'Ilm al-Kalam, Islamic theology, Kalam, ijtihad, wasatiyyah

The nonviolence which is the policy of refraining from the use of violence to gain one's objectives is one of many noble goals for humans living on this earth planet. Human noble goals are found in many religions that teach kindness and peace for humans to live in this world. Some of the examples are Buddhism that teaches simplicity, Christianity that teaches love, Confucianism that teaches wisdom, and Islam teaches compassion for all created beings. In the context of Indonesia today, something paradoxical is noticeable because the religion that essentially teaches noble values, teaches coolness, peace, tranquility, compassion and other ideal values, looks like a hard and fierce one. This religion is often associated with radicalism, extremism, and even terrorism showing its ugly and frightening faces. In the present context, the forms of conflict, violence and religious wars are usually associated with the rise of religious fundamentalism among Muslims in Indonesia and other parts of the world. Religious fundamentalism expresses its socio-political forms in extremism and violence as a reaction to the conditions of human life considered to be far from the ideal life for Muslims. This expression or form of fundamentalism sometimes becomes terrible or horrible.

The present condition shows that there is a missing of a good and noble value so that we need to revive the spirit of nationalism and the concept of wasatiyyah or the concept of moderation in Islam as a foundation for establishing harmonious and progressive societies and government in Indonesia. As a developing nation and government, Indonesia has some problems in her marching peacefully, progressively and properly toward attaining the noble goals of human

\footnotetext{
${ }^{1}$ Fuad Mahbub Siraj* (corresponding author), Ph.D., lecturer at Department of Philosophy and Religion, Paramadina University, JAKARTA 12790, Indonesia, email: fuad.siraj@paramadina.ac.id; Ridwan Arif, Ph.D., lecturer at Department of Philosophy and Religion, Paramadina University, JAKARTA 12790, Indonesia, email: ridwan.arif@paramadina.ac.id; Efendi, M.Ag., lecturer at Department of Aqidah and Islamic Philosophy, State Islamic University Imam Bonjol, PADANG 57126, West Sumatera, Indonesia, email: effendi_1974@yahoo.com.
} 
beings if their nonviolence forms of expressions and actions are not well accepted by all Indonesians who are of multi-religions, multi-ethnics, multi-races and multi-cultures.

In the Indonesian context, Pancasila has been the theological and philosophical foundation of all Indonesians exhorting them to live peacefully and harmoniously. Pancasila is the main national foundation to maintain the harmonies communications and lives among the various religious communities in Indonesia. Unity in diversity is considered or accepted as an Indonesian uniqueness by itself, a representation of the symbol of unity in diversity and diversity in unity that was born from the womb of the Indonesian nation in line with the values contained in each religion found in Indonesia.

In the context of Muslims in Indonesia, the problem shows that something is missing from their religious understanding regarding the tendency to read as well as to understand the fundamental aspects of their religion. One of Islamic science that discusses the fundamental aspects of Islam by using reason and naqal (Nasution 1972: iv, 79) is the kalam. It is the science that discusses the existence of God who has created the universe and the relationship between God and His created universe covering humans and other beings.

The Department of Philosophy and Religion of Paramadina University Jakarta and the Faculty of Ushuluddin majoring in the Aqidah and Islamic Philosophy of IAIN (State Institute of Islamic Studies) and UIN (State Islamic University) have offered the kalam and they should have raised the kalam to be at par with other theoretical and philosophical subjects or courses such as philosophy and metaphysics. Moreover, there have been Muslims who have questioned the existence of the kalam and its significance or usefulness to Muslims to learn and teach the kalam at Muslim colleges and universities.

There have been negative attitudes and statements about the kalam and its significance. One of the negative statements about the kalam came from Tarmizi Taher (then Minister of Religion of the Republic of Indonesia). He was reported to have said that the Faculty of Ushuluddin would be eliminated from IAIN. He allegedly intended this because the Faculty of Ushuluddin was not relevant to the overall Indonesian development program. This impression can be interpreted that the study of the kalam in the Faculty of Ushuddin of IAIN will come to an end because that faculty which offers the Kalam will be eliminated as aside by Tarmizi The similar negative idea was also expressed by Prof. Dr. A. Qadry Aziziy, MA (at that time the DirectorGeneral of Islamic Education of the Ministry of Religion of the Republic of Indonesia) that the study of the kalam was obsessed. Therefore, in the future, the kalam is not needed in Indonesia.

By referring to some negative opinions above mentioned here, we, the authors of this article, plan to discuss the kalam as a foundation in the development of theoretical sciences in Islam and the significance of the kalam to the concept of wasatiyyah in Islam. We are of the positive view of the kalam and it can contribute to a kind of harmonious and peaceful living among Indonesians of different religions and races moving toward a peaceful and progressive nation of Indonesia.

\section{The Essence of the Kalam and Its Naming}

In the history of the sciences in Muslim medieval period, the kalam stood -alone as an Islamic discipline, discussing the fundamental aspects or teachings in Islam. What is meant by the human aspect is the matter of divinity through reason and naqal (Nasution 1972: iv, 79). There have been many books written by Muslim scholars on the kalam which is different from other sciences initiated and developed by the Muslims in the medieval era.

The kalam is the science that discusses the existence of God and His relationship with the created universe including humans. The word kalam in Arabic language can be understood as a speech, saying or expression. interpreted. In Arabic linguistics, the kalam is words arranged into a sentence that has its meaning. In Islamic religious knowledge, the kalam can be referred to the speeches or words of Allah as found in the Holy Quran and the Holy Quran is referred to as the 
kalam of God or Allah by Muslims because they believe the speeches of Allah received by His last and final prophet and messenger Muhammad peace be upon him the seventh century AD are the contents or verses of the Holy Quran. Because of the Holy Quran is the words or speeches of God available to human beings to read and understand the words of God in Arabic language, the Muslim theologians during the rise of the kalam in the Muslim medieval era made the topic of discussion on the nature of the kalam of Allah in the Holy Quran. Some Muslim theologians in the 9th and 10th centuries AD held that the kalam of God in the Holy Quran was created and some others held that the kalam of God in the Holy Quran was eternal. From these two opposite views of Muslim theologians, the name for the kalam, was accepted because it discussed the nature of the kalam of God in the Holy Quran as the polemical topic among them.

Due to the opposite views among Muslim theologians on the nature of the kalam of God in the Holy Quran, they contributed to the theological test known as the theological inquisition or the mihnah in Arabic language This historical event known the mihnah or the inquisition to examine or test the Muslim belief on the nature of the kalam of God in the Holy Quran. For Nurcholish Madjid, the mihnah in Islam must be distinguished from the inquisition in the Western perspective. In Islam, this is done under a kind of Islamic 'rationalism' or freedom of thought which is the Mu'tazilite understanding, against those who consider it to be a barrier to that freedom. Whereas the Inquisition in in the West in the name of fundamentalism and narrow understanding of religion against the free mind became the understanding of scientists and philosophers who learned much from the Islamic heritage (Amin 1936: 34-35).

The kalam can also mean human words, then this science is called the kalam because the mutakallimun argued in defending their own opinions as well as in disputing the opinions of their opponents (Nasution 1972: iv). While the use of the term kalam as an Islamic discipline was first coined by the Mu'tazilites during the Caliph al-Makmun (813-833) of the Daulah Bani Abbas (Yusuf 1990: 2). This can be explained here that the Mu1taxiltes argued and defended their view that the kalam of God in the Holy Quran was created and at the same time they disputed and argued against the view of their opponents that the kalam of God in the Holy Quran was not created but eternal.

Another name for the kalam is the tawhid because its main goal is to firmly establish rationally the Oneness of God. The kalam is also called the 'ilmu usuluddin because its topics of discussion are related to Islamic articles of faith which are considered fundamental and essential in Islam. In addition, the kalam is also called the 'ilm al-aqa'id (the science of articles of faith or belief) because it discusses and presents rationally Islamic religious beliefs. Western writers used Islamic theology for the kalam, and Indonesian scholars and writers used Teologi Islam in Indoensian language for the kalam because it studies theological dogmas or doctrines.

The definitions of the kalam are different because the different aspects of the kalam were emphasized by the definers. Al-Ahwani defines that the kalam is a science that strengthens religious creeds by using rational argument (al-Ahwani 1962: 18). Ibn Khaldun said the kalam contained rhe rational arguments to defend the faith or the imaniyah and to refute and reject the heretical groups and their creeds deviated from the salaf and ahlus sunnah Ithe Sunnites) (Ibn Khaldun 1981: 580). Abduh used the name 'ilm al-tawhid for his book on Islamic fundamental creeds. Such as the nature of God, His necessary attributes and qualities and His affirmative and negative attributes His messengers and prophets and their responsibilities, their necessary attributes in their preaching and spreading the religions from God to their people in their localities. The prophets and messengers of God were chosen by God to receive the revelations from God for themselves and their people. As the prophets and messengers of God, they follow and God's commands and do not God's prohibitions. They also do the permissible acts permitted by God to them (Abduh $1366 \mathrm{H}:$ 7).

Although the definitions of the kalam are varied, the core topics or themes in the kalam Allah's unity God's words, seeing God in the hereafter and the anthropomorphic verses related to God, God's justice, God's absolute power and will, God's actions, the position or status of human reason, the function of revelation, faith (belief) and kufr (disbelief). The results of the formulation 
of the kalam gave birth to the types of approaches used for the kalam, the rational approach advocated by the Mu'tazilites, the traditional approach advocated by the Asha'arites and the middle approach between the rationalist and the traditionalist approaches advocated by the Maturidites.

The rational approach of the kalam places human reason at a significant position when humans make efforts to understand the fundamental creeds in Islam based on the Holy Quran and the Prophetic traditions in Arabic language. The advocates of the rational kalam propose the solution to humans when they have problems in understanding the attributes of God which are anthropomorphic such as God's hand and face that they should be understood metaphorically since God is totally different from humans and their attributes. The advocates of the rational kalam uphold that humans are free to will and act on their wills since God has granted humans the power or ability to will and act based on their wills and powers created to them by God. In the West, humans are understood to have their free wills and actions in their lives, and they are responsible for their good and evil actions respectively. Regarding the divine justice, the advocates of the rational kalam uphold that human reason is able to comprehend the justice of Allah, by pondering and reflecting on Allah's created beings including humans.

Meanwhile, the advocates of the traditional kalam place human reason or intellect lower than the position granted by the advocates of the rational kalam in understanding and comprehending about Allah, His attributes and actions as well as human attributes and actions. For the advocates of the traditional kalam, humans are not free to will and act even though Allah created humans with their will and power to will and to act following human will. This view is closer to the understanding of Jabariah, the Jabarites or the fatalists among some Muslims. God's absolute power and will remain with God in His dealing with human will and power to act during human life in this world (Nasution 1989: 2-3; 15-16).

The advocates of the kalam who are in the middle approach between the rational kalam and the traditional kalam emerged from those opposing approaches of the kalam in understanding and comprehending about God, His attributes and His actions as well as His will and power in connection with human will and power to will and to act according to human will and power.

With the existence of the three approaches of the kalam as mentioned here, it is very beneficial for Muslims who are following their ability level of reasoning power at various levels as lay, moderate or intellectual persons to review the three approaches of the kalam. They are not in conflict with the fundamental teachings of Islam because they rationally and textually confirm the existence of God who is the creator of the universe including humans. In Islam, the knowledge about the existence of God, His attributes, His actions and His communication with humans are fundamental things called in Arabic al-muhkamat, namely the set teachings of Islam understood as the absolute, universal, eternal and unchanging and must not be changed. For examples, humans who deny the existence of God, they are atheists and they cannot be Muslims because Muslims have to believe in the existence of God who revealed His relations to His human prophets and messengers. Believing in the existence of human prophets and messengers of God is another fundamental teaching of Islam. The Christians and the Jews who did not believe in the last and final prophethood of Muhammad peace be upon him were not Muslims, not because they did not believe in the existence of God but they were not Muslims because they refused to believe in the prophethood and messenger ship of the last and final prophet and messenger of God named Muhammad in the 7th century AD in Arabia in Arabic language.

The number of fundamental and credible teachings in Islam is very small. Some Muslim scholars summarized them just into the six articles of Muslim faith namely Allah, His human prophets and messengers, His revealed books, His angels, His eschatological events after the doomsday, and His explained criteria of human goodness and evilness in order for humans to be rewarded with the good and comfortable lives in the Paradise or to be punished with terrible lives in the Hell in the hereafter. 
There are some teachings of Islam considered to be relative and changeable in different periods and different locations based on the existence of the new problems among Muslims. They are not fundamental sets of Islamic teachings. They are relative and can be changed even sometimes they must be changed or modified accordingly. These teachings of Islam are called in Arabic al-mutashabihat. So, the mutashabihat types of Islamic teachings in the kalam can be changed or modified or taken away and they can be put aside from the kalam if Muslims thought that they are useless to be presented to the Muslim students in the colleges and universities in Indonesia. The ideas or proposals no to teach the kalam for the Muslim students at Indonesian colleges and universities are not good ideas or proposal since to be knowledgeable Muslims they must learn and firmly believe in the articles of Muslim faith which are fund in the kalam Therefore, the three approaches of kalam as advocated by their opponents do not make Muslims change their religion and become atheists from the advocates of the kalam because they all firmly establish rationally and textually the existence of Allah who is the source of the religion named Islam, the religion of Allah as said in the Holy Quran(3:19). Allah will not accept the beliefs and actions of humans who have decided to make their religion other than Islam and they are the losers in the hereafter as said in the Holy Quran (3:85).

The difference between the kalam or Islamic theology and other social sciences and humanities is due to their different focuses and topics of discussion. Theologies other than Islamic theology, for example, probably begin with the discussion about God by posing the questions, does God exist or does He do not exist. If the answers from such discussion lead to the affirmation of the existence of God, they probably believe in the existence of God. If the answers lead to the negation of the existence of God, they probably become atheists.

According to Nurcholish Madjid, the kalam has existed specifically in Islam among Muslims, and the kalam has not existed and will not exist in other religions among non-Muslims. In essence, the kalam has no counterpart in the growth of other religious thought. This is very clear from the translations of the kalam in English. The kalam was translated as Dialectical Theology, Speculative Theology, Natural Theology, and Philosophical Theism. These English translations for the kalam show the aspect of a very basic difference between the kalam that it is not dogmatic like other dogmatic theologies (Madjid 1990: 7).The main aspects in the kalam consisting of human understanding efforts made by the mutakallimun to understand and comprehend the Islamic articles of faith or belief contained in the Holy Qur'an and Hadith and their goals are to establish and defend Islamic creeds and dispute and then reject the creeds which are false and contrary to the true Islamic creeds based on the Holy Quran and Hadith supported by human reasoning approaches.

The Muslim traditionalists or Ahl al-Hadith who lived in the early centuries of Hijrah were not happy with the kalam because they thought that the mutakallimun used the dialectical and polemical methods in their discussions against their opponents following the dialectical and polemical methods used by the ahl al-ahwa' wa al-bid'ah (the followers of deviated and lustful sects) in Islam. The Muslim mutakallimun or ahl al-kalam did not agree with the negative view of the Muslim traditionalists about the kalam. For the mutakallimun, the kalam is the science for Muslims to talk, discuss, formulate, explain, or defend Islamic creeds (Dahlan2001: 25). In any case, the kalam as the name for the theological and fundamental creeds of Islam has existed in Muslim history of Muslim sciences and it still exists up to this day. This reminds us more about how hard the efforts of the mutakallimun in the past in formulating and defending knowledge in the field of the Islamic creeds and fundamental aspects of Islam.

\section{The Existence of the kalam}

Islam is a rational and dynamic religion. Islam is compatible with human dynamism and rationality. Any religion that its functions are to regulate human life is dynamic, if the religion is not dynamic, humans will abandon it because it inhibits human dynamism. 
Islam is a revealed religion. The Holy Quran in Arabic language is the first source of the revealed religion named Islam. This means that the Arabic text in the Holy Quran is not from the Prophet Muhammad peace be upon him, he received the revelation in Arabic language from Allah or God. Another name for the revelation received by him from Allah is the word of Allah or the kalam of Allah. Therefore, the Arabic text of the Holy Quran is eternal and unchangeable as well as uncorruptible. if the Arabic verses in the Holy Quran were replaced with their synonymous Arabic texts or verses, or its sentence structures were changed or reconstructed or its verbs, nouns, pronouns and prepositions were substituted or changed, the Holy Quran would be corruptible like the earlier revealed revelations found in the Torah and the Bible. The Holy Quran clearly states that the earlier revelations were corrupted by their followers and the Holy Quean is free from the corruptible efforts made by humans. The Holy Quran remains as the uncorruptible and unchangeable revelation received by the last and final prophet and messenger of Allah for all humans and jinn. It is an absolute and eternal revelation from Allah for humans and jinn to be accepted and adhered by them in their lives in this world if they plan to go to the Paradise created by Allah for the lives of humans and jinn in the hereafter. There are only two opposite abodes in the hereafter called the Paradise and the Hell for humans and jinn to choose while they are still alive in this temporary planet of the earth through their beliefs and deeds. Allah promises the Paradise for the humans and jinn who adhere to His religion Islam and Allah promises the Hell for the humans and jinn who do not adhere to His religion Islam.

Likewise, the translation of the verses of the Holy Quran into other languages such as English, Malay or Chinese does not become the absolute revelations of the Holy Quran since the translated verses of the Holy Quran in other languages are made by humans. They can be called the translated or the interpreted verses of the Holy Quran. Since the translations and interpretations of the Holy Quran are by humans, they are no longer called absolute revelations; they are relative and inclusive culture. In other words, the interpretation and translation of the Holy Quran are not binding for humans, meanwhile the revelations (verses) in Arabic texts of the Holy Quran are binding for humans (Zar 1996: 1).

Unlike the basic nature of the Holy Quran as the first source of Islamic teachings, the Hadith or the Prophetic tradition, as the second source is not a revelation in the same meaning and nature as the Holy Quran. Generally, the Hadith contains the words and deeds of the Prophet Muhammad, peace be upon him. He is protected from sinful errors and mistakes and becomes the protected prophet the ma'sum. In other words, if there was something wrong with the words and actions of the Prophet, he would immediately get God's guidance to correct the mistakes or errors. If he did get a reprimand from Allah, his words and deeds are true. Besides, there are also the qudsi traditions, namely the traditions whose ideas or meanings were put into the heart of the Prophet who then immediately expressed the ideas or meanings in his own Arabic words. All of that is not a revelation but the hadith. It functions as an explanation of the contents of the Holy Quran. As for the traditions that are considered the most reliable and authentic, they are called or categorized as the Hadith mutawatir which is very few.

Some verses of the Holy Quran are in the form of basic principles and broad outlines without further explanation of the purposes, details and how to implement them. These verses of the Holy Quran turn out to be general and basic, and they are compatible with human dynamism. Humans are dynamic beings because they often experience changes and develop according to the progression times and developments around them. If the absolute and fundamental verses of the Holy Quran were numerous and detailed, then the human dynamism would inhibit human development and dynamism's Therefore, it is very appropriate that the questions of social life or worldly matters are left by God to the human mind to think and manage them.

Nevertheless, it does not mean that Islam is understood as a religion like other religions separating the religious affairs from the human worldly affairs or fields. Islam teaches the basic principles and fundamental good values covering social, economic, educational, political and managerial aspects of human lives. Therefore, we come to know for examples systems attributed 
to Islam such as Islamic education, Islamic studies, Islamic schools, Islamic colleges, Islamic university, Islamic politics, Islamic finances, Islamic banks, Islamic governments and nations. However, these systems and institutions are the creations and inventions of humans through their understanding and comprehending of the verses of the Holy Quran as well as some traditions of the Prophet Muhammad, peace be upon him. which come in the form of basic principles. It needs to be stated that the Holy Quran does not command the formation of a particular system from time to time in detailed manner. The Holy Quran just provides the fundamental and basic principles and essential values for humans to initiate and establish for examples the particular forms of government $t$ rule over Muslims such as the caliphate system of government, the monarchy and the democratic system of government.cy Therefore, what form of system is born of human reason as long as it is following the Quran, so it can be said to be Islamic in a sense that the system is the product of human reasoning and ideas. it can change and be changed without changing the basic principles or verses listed in the Holy Qur'an. These verses are the basis for Muslims from the period of the Prophet Muhammad to the end of time or the end of the world.

So, the verses of the Holy Quran can be divided into two groups. The verses of the muhkamat, the verses whose meanings are definite as given by the Arabic texts and cannot be interpreted into other meanings. The verses of the mutashabihat, namely the verses whose meaningn are indefinite or uncertain and can still be interpreted into other meanings. In the Holy Quran, its most verses are the mutashabihat and from these verses, the process of the development of Islamic teachings occurs in various human fields.

From the descriptions here above, it can be concluded that the teachings of Islam consist of two groups:

1. The teachings of Islam that are absolute, universal, eternal, unchanging and unalterable, as contained in the Holy Quran with its Arabic text and in the hadith mutawatir, and;

2. Islamic teachings that are relative and changeable; they can change or can be changed, even sometimes they have to be changed due to certain new factors. The teachings of Islam in this second group are the teachings of Islam derived from the human ijtihadi efforts involving human reasonings and experiences.

It is worth mentioning, the kalam discusses the fundamental aspects of Islamic teachings for all Muslims to become their beliefs or creeds which are the foundation for their actions or deeds in this world. Therefore, this knowledge covered by the kalam is important and must also be used as a guideline in conducting and teaching Islamic studies. Thus, the kalam still exists today as well as the existence of other Islamic sciences, such as the fiqh, Sufism, Islamic philosophy, the sciences of Hadith and of the Holy Quran or the 'ulum al-hadith and the 'ulum al-qur'an Muslim communities and Muslim nations. These sciences, for examples, do not discuss the fundamentals or al-muhkamat but they cover the aspects or the topics under the mutashabihat of the that are not explicitly and definitely mentioned in the verses of the Holy Quran and the mutawatir hadiths. In other words, they only describe or interpret the main fundamentals of Islamic teachings by their reasonings and ijtihad efforts. Hence, the kalam can be considered as the science covering the fundamental creeds or beliefs of Islam as understood and interpreted by the kalam scholars. This is also true to consider the fiqh as the science covering the fundamental laws of Islam as understood and interpreted by the fiqh scholars, the fuqaha'.

The kalam often focuses on the metaphysical-transcendental-normative ideas, without any connection with the practical aspects of those ideas. This also happens for the study of the fiqh such as the study of Islamic criminal laws that cannot be practiced where and when the country does not implement Islamic criminal laws. If the kalam studies only the works of the past kalam scholars for the sake of their heritages without any connection with the present issues and problems, it is probably not very useful for the present Muslim communities. However, the fundamental beliefs or creeds covered by the kalam are important and significant for the past and 
present Muslims The understandings and interpretations of the past kalam scholars about the fundamental creeds in Islam can be used as the guide to face the present problems faced by the present Muslims in their understandings and elaborations of the fundamental Islamic creeds. The understandings and the elaborations of the past kalam scholars about the fundamental creeds in Islam seem sophisticated for the present Muslims leading them to have the negative views on the kalam. The present Muslims can use the understandings and elaborations of the past kalam scholars as a historical guide for the present Muslims who wish to study the kalam. We cannot say that it is useless to study the past kalam in the present Muslim communities. If we hold such negative view about the past heritages of Muslim history and civilization, we do not have the historical data and information for the present and future Muslims. The Holy Quran contains the historical data and information about the past human communities who opposed their prophets and messengers of God and they were punished by God such as the human communities during the time of Noah and Moses. Can Muslims say that the historical data or narratives in the Holy Quran on the past human communities are useless for the present and future Muslims?

What is offered by the kalam is the past understandings and elaborations of the past kalam scholars as well as their polemical, dialectical, rational and contextual methods for understanding and comprehending the fundamental creeds in Islam. The present and future Muslim students and scholars of the kalam should see these two positive contributions of the past kalam scholars rather than looking at them negatively.

As briefly mentioned above about the existence of the three approaches of the past kalam scholars namely the rational, the traditional and the middle-way between the rational and traditional approaches as represented by the Mu'tazilites, the Ash arites and the Maturidites, the present Muslim students and teachers are able to choose the better kalam approaches for them to focus in their studies of the kalam as well as other Islamic studies.

It is probably not wrong to say that if some Muslim students of kalam have adopted the rational characteristics of the kalam, they are possibly more dynamic and rational than some other Muslim students who have adopted the tadeonal characteristics of the kalam.

Some Muslim scholars think that Islamic studies should use the two attitudes or approaches namely rationally and openness in order to inculcate the attitudes of tolerance and moderation among the students of Islamic studies in Indonesia. If the rational characteristics of the kalam are accepted and adopted by the students of Islamic studies, then their lives are probably more dynamic than the students who accepted and adopted the traditional characteristics of the kalam. Herein the kalam can contribute significantly to the understanding and implementing the Islamic wasatiyyah.

\section{Wasatiyyah in Islam}

The diversity found in the universe seems to be no longer attributed to the wiil and wisdom of God who has created the universe. Some humans think that the differences among humans are caused by their natural, physical and biological needs. Hence, they need to lean on each other, get to know each other and find themselves in a homogeneous whole at the universal level. The Holy Quran of the chapters of al-Hujurat 49: 13 and of al-Maidah 5: 48 explicitly explains that God created humans in the type of male and female, then made them national and tribal (Misrawi 2007: 303). Essentially the verses of the Holy Quran (49:13 and 5:48) point out that God who has created humans and their diversities, they are not created by humans themselves. The will and wisdom of God have led to the creation of humans and their diversities. The Holy Quran also mentions that God has created humans and jinn to worship Him alone $(51 ; 56)$. Human diversities are historical and factual data for humans to test them in their lives in this world and how they play their roles among the diversified humans for their own goodness or evilness as well as to other humans. 
The mass media paid a greater attention to the issues of violence linked with some religions, and with intolerance, fanaticism, and extremism developing rapidly around human societies or communities. In April 2014 Indonesia was given the bad record by the United Nations regarding human rights and the violence in the name of religion. SETARA noted the UN report which reads:

"In Indonesia, for example, minority groups such as the Ahmadiyya, Bahai, Christian, and Shia face physical attacks from Islamic militant groups with minimal involvement from the government. Although the Supreme Court has issued a ruling that affirms the rights of the Taman Yasmin GKI congregation to erect their church building in Bogor, West Java, the local government sealed the building in 2010 and has since prevented the congregation from entering their church"(https://equivalent-institute.org/en/kontras-indonesia-return-includein-notations-dough-ham-dunia/. Retrieved 29 November 2017).

Imdadun Rahmat, the chairman of the National Commission on Human Rights, said in his annual report that the cases of intolerance over freedom of religion and belief increased significantly. Throughout 2016, based on complaints received by Komnas HAM, there were 97 cases recorded. This shows an increase because there were 76 cases in 2014 and 87 cases in 2015 (https://www.komnasham.go.id/index.php/news/2017/01/16/276/pada-2016-intoleransiincreased.html, September 8, 2017). These recorded cases are sufficient empirical evidence that at present the community tends to be fanatical and exclusive of differences. Awareness of the importance of being moderate (wasat) in dealing with diverse realities of life is no longer used as a guide in social life. Thus, the religious pluralism among humans (their communities) is inevitable. Muslims are demanded to be able to respond to the differences covering the differences between one religion with another religion such as the differences between Islam and Christianity or Buddhism or Hinduism, and the differences within one religion due to the different sects of that religion. For Muslims, a better way or method to response to the religious pluralism is the wastiyah in Islam.

In its essence Islam views humans and humanity in a very positive and optimistic paradigm. Islam commands to invite someone to the way of Allah through a wisdom, a good advice and a sound and polite dialogue as mentioned in the Holy Quran, Surah al-Nahl (16: 125) clearly stating:

"Call upon people in the way of your Lord with wisdom and good teaching, and debate with them in a good way. Indeed, your Lord is He who knows better who is lost from His ways and He who knows better who gets guidance" (al-Quran $16: 125)$.

In the translation of the above verse of the Holy Quran (16:125), the sentence is not accompanied by any hostility and hatred because of any difference. This is the command of Islam that should be acknowledged and implemented by the good people among all humans because they believe in Allah and they also command the good and prohibit the evil among humans as mentioned in the Holy Quran, Surah Ali Imran (3: 110).

The understanding and interpretation of the texts or verses of the Holy Quran should be oriented to the need for a harmonious relationship between humans to create some kind of cooperation and togetherness in some human activities. This attitude is an interpretation of the universality of the Holy Quranic mission itself. According to the Holy Quran, every human being has his rights to live, to communicate, to interact based on human norms and values., without the slightest discrimination of ethnicity, color, culture, language, religion and all other forms of primordial ties (Amuli 2011: 131), because in God's eyes all humans have the same honorable 
status as the children of Adam, the first human father created by Allah to temporarily domicile in this world planet. The Holy Quran, Surah al-Isra' (17: 70) states:

"And verily We have glorified the children of Adam. We transport them on land and in the sea, we give them good fortune, and We prioritize them with perfect advantages over most of the creatures that We have created." (QS17: 70)

It there are still individuals or groups continue to try to prioritize their good feelings about the truest (truth claim) for their beliefs or religions, they can feel so for themselves; they cannot do for other human beliefs or religions because the Holy Quran, Surah al-Kafirun (109: 6) evidently states that for you is your religion and for them are their religions. The religious plurality and differences between Islam and other religions are the realities of human religions and human communities as mentioned in the Holy Quran (109: 1-6). Muslims have to understand and acknowledge the existence of the differences between Islam and other religions.

The Quran names the people of Muhammad, peace be upon him, as the khairul ummah, the best people (Ali 'Imran 3: 110) and the ummah wasatan, the moderate people (al-Baqarah 2: 143). Both names or denominations were granted to the Muslims or the people of Muhammad, peace be upon him, when they were able to overcome a variety of issues such as social diversity, living in diversity with the Jews and the Christians, and then the Muslims under the leadership of Muhammad, peace be upon him, became a pioneer of world civilization (Hanafi 2012: 338). Both names or titles namely the best people and the moderate people granted to the early Muslims led by Muhamamd peace be upon him, should be the human community model able to be followed and practiced as an ideal model for today Muslims. But the fact is not, Muslims seem to be fragile in their solidarity with fellow Muslims, loosening of their kinships, and their differences are no longer used as a mercy or grace but instead their differences have become their instruments for the weakening and destroying among themselves, and sometimes the differences have led to, killing among Muslims including the innocent Muslims.

It seems that the concept of wasatiyyah is a concept in Islam that is used as a reference in every Muslim thought and action because this concept is able to avoid any extreme thought and action coming of Muslims. Lately, due to the existence and presence of extremism, intolerance and fanaticism among Muslims, some people who do not understand the teachings of Islam feel afraid or scary of Islam and they distance themselves from Islam. It is true to assert that the presence of extremism and fanaticism that causes the emergence of intolerance towards differences among Muslims themselves is able to endanger and inflict Muslims themselves as well as Islam which is their religion.

Seeing the various problems that these authors described above, it is necessary to reexamine the verse of the Holy Quran, al-Baqarah 2: 143, as a foundation on which to become one of the religious texts which clearly shows wasațiyah.

"And likewise, we have made you (Muslims)" people of the middle ", so that you may be witness to the (act of) people and the Messenger a witness over (deeds) you." (al-Quran 2: 143).

The good qualifying race, the ummatan wasațan is stated in the Holy Quran (2:143). God made Muslims as the ummatan wasatanin in order to bear witness to human actions. The Arabic term ummatan wasatan is often interpreted as a just, the best, elected, to take a middle and balanced path by the mufassirun (Imani 2003: 370; Basyir 2012: 85; Al-Mahalli and Al-Suyuthi 1416 H: 25; Hamka 2003: 332; Ibn Kathir 1419 H: 325).

The Arabic word wasat in the sentence ummatan wasatan was originally interpreted as all that was good according to the object (Hidayat 2016: 18). The intermediate position between two opposing positions can also be understood in all that is good and commendable according to 
its object (Shahabuddin 2007: 1070-1071). Al-Tabari said the Arabic word wasat means the chosen, the best, and the fair. Being chosen and best, because of the character of the person "being fair" (al-Tabari 1992: 8-10).

Al-Qurtubiy interpreted the Arabic word wasat to mean fairly. The origin of this Arabic word is that everything that is most praiseworthy is the middle one. In this context, it does not mean who takes a position at the center or in the middle in a problem (Al-Qurtubiy $1993 \mathrm{H}$ : 104105).

Likewise, according to Fakhruddin al-Razi in interpreting the Arabic word wasat is justice (al-Razi $1420 \mathrm{H}:$ 84). The fair approach will be better if it is in the middle, which is balanced and equal in all respects. As the Prophet, peace be upon him, said, Khair al-Umur Ausatuha, "As best as possible everything is intermediate" (Al-Razi $1420 \mathrm{H}$ : 84). In other words, the good is between the two extremes. Courage is the middle between carelessness and fearfulness; generosity is the middle between wasteful and miserly.

The use of the Arabic word wasat in the Quran gives the understanding that Islam does not want extreme groups, because it symbolizes shortsightedness and rigidity in dealing with problems. On the contrary, the Muslims who ideologically adhere to a system of balance are not the same like other humans who are drifting in the life of materialism and ignorance of spiritual life at all, nor are they like people who only pay attention to spiritual life and neglect physical and biological aspects of life. The middle position calls on Muslims to appear to have social interactions, dialogue and be open with all parties who have different religious, cultural and civilizational backgrounds. Such an approach can bring us to apply and testify fairly to all parties because it is a fair attitude between the two different groups, not inclined to one group. If this concept of the ummatan wasatan in Islam is fully understood and realized by Muslims, then they will always interact, dialogue, and are inclusive without prioritizing the priority.

\section{The Reconstruction of the Kalam and Its Relevance to the Concept of Wasatiyyah}

It has been described earlier on in this article that the kalam is an Islamic science which is the product of the 'ulama or Muslim religious scholars in the early days of Islam in the field of Islamic creeds or beliefs. This science is certainly different from the Holy Quran as the main guideline in Islam, which agreed upon the text must come from God. In other words, the text of the Holy Quran is final and cannot be contested anymore. Whereas the kalam as a result of the ijtihadi efforts of the mutakallimun about Islamic creeds is not a doctrine that must not be changed. Since the kalam was the result of the ijtihadi efforts of the past mutakallimun and it was thought to be the sophisticated one, it is not sacred, the kalam can be changed and sometimes it must be changed because it does not fit with the times. If this is the nature of the kalam, today Muslims should not see the kalam as a useless science existed in the past Muslim communities.

The kalam and other Islamic sciences developed by the past Muslims were scientifically and rationally established and highly developed. Some of the scientific developments among the past Muslims were the products of their knowledge, experience or dialoged with fellow Muslims and some non-Muslims. Knowledge in Islam is still open and attainable by human minds and applicable by human hands. The knowledge door in Islam is never closed. Knowledge in Islam does not stagnate. So the famous two learned Muslims Imam Abu Hanifah and Imam Shafi'i were reported to have said that: Hum rijal wa nahnu rijal (they are experts in their fields and we are also experts in our fields), the only permanent aspect of science is research (Azizi 2003: 21). Based on that, according to these writers, the kalam this needs to be reconstructed again, so that this discipline is not rigid. Efforts in this direction need to be done seriously and courageously and systematically to redevelop or reconstruct the kalam of the past kalam scholars. In other words, it is necessary to make a new "ijtihad" which has been considered as the "good or gold standard". The planned and desired ijtihad is certainly adjusted to the needs of the times that refer to the Islamic mission for the benefit of the people. On the other hand, we certainly don't want to lose the historical continuity of the kalam. Their efforts in the past were not wrong but 
their efforts were conditioned by their environments, experiences as well as human political and religious factors and time limitations. According to A. Qodri Azizi, there is a difference between the studies conducted by Islamic scholars and Orientalists, so Orientalists will not hold the title of Mujtahid. This is not only they do not believe and also because they have no intention to practice it (Azizi 2003: 56).

In reconstructing the kalam, its philosophical methods with radical analytical-critical approaches can be used. On the other hand, it can also be used as a scientific approach that is used in social sciences, of course, with a note of science that matches the direction of science. Then the kalam fields are filtered according to present uses. This is intended to prove that Islam is a rahmatan li al-'alamin (al-Anbiya' 21: 107). A critical approach has also been carried out by classical Muslim religious scholars or the 'ulama in the past, such as al-Ghazali's criticism of alFarabi and Ibn Sina in his book: Tahafut al-Falasifat, also Ibn Rushd's criticism of al-Ghazali's criticism in his book Tahafut al-Tahafut.

If we take into consideration the relevance of the kalam to the Muslim conditions today, one of the many steps of renewing or reconstructing the kalam is to do a "Shifting paradigm" from the classical kalam paradigm to social theology; as a new paradigm since the present Muslim community has become a global population in the multicultural era. Moreover, the formation of a nation-state has caused Muslims to split into various territorial areas of the national countries such as Malaysia and Indonesia where Muslims must live together with other religious communities. So, an inclusive attitude and social ethics are needed to create harmony for a progressive government.

The paradigm of social theology must firstly rely on the understanding of the Holy Quran as a paradigm. The understanding of paradigm, in this case, refers to the understanding that was built by Thomas Kuhn, that social reality is constructed by a mode of thought that ultimately produces a mode of knowing. In this sense, the Quranic paradigm is a model of the construction of knowledge that enables humans to understand their historical realities as the Holy Quran understands reality based on worldviews (Kuntowijoyo 2006: 11).

Based on the understanding above, the paradigm contains several elements, namely; as a fundamental view agreed upon by a group of scientists; the mutakallimun. The objects or subjects of knowledge that should be learned in the kalam must be agreed by the present mutakallimun. They also should agree on the scientific methods of the kalam to study the objects of research covering the concepts of divinity and eschatology. The concepts of the paradigm can be compared with Gadamer's basic assumptions or presumptions, and the fundamental cognitive structure Michel Focault (Sugiharto 1996: 92).

Social theology has its epistemological basis in the Holy Quran. Related to this, we, the writers, prefer to borrow Kuntowijoyo's view of the classification of science in the Holy Quran. According to Kuntowijoyo (Kuntowijoyo 2008: 262), the Holy Quran explains that there are two categories of knowledge; namely, the knowledge of the horizon and the science of humanity itself or humanities (anfusihim) as we see in the Holy Quran, Fusilat (41:53). In explaining these words, Kuntowijoyo emphasizes the meaning of the word 'anfusihim as a description of the Holy Quran about human sciences or what is often called humanities. In this context, Kuntowijoyo understands humanities as sciences that dialectically continue to be in line with the development and progress of the times so that there will always be a continuous meaning, due to changes in structure and space in human life. The kalam discourse can be categorized as "science" of a socialhistorical nature (humanities), although it is based on the revelation because the kalam originally came from the efforts and struggles of the early Muslim religious scholars over their pertinent problems by producing the kalam for their concerns. From this understanding, social theology as a category of sciences by themselves "anfusihim" is a way for humans to understand and respond to their social context, to realize the manifestations of the deity on earth.

In the modern and post-modern eras, a theology which is only focused on the question of God alone (or the theocentric science) and does not link with the discourse to the problems of 
universal humanity, will gradually become out of date. Therefore, a theology which deals with abstract and scholastic problems will lose social relevance to contemporary challenges: humanity, religious pluralism, structural poverty, environmental damage and others (Abdullah 1995: 42).

The term "social theology" is intended as a new perspective on the theological realm that is anthropocentric, open and dialogic so that the theological dimension truly lives in the daily life of the community and does not seem to be always as abstract as metaphysical. Social theology focuses more on the real challenges faced by religious communities in the world and contemporary civilization.

The phenomenon of plurality and multi-culturality is increasingly rapid, demanding Muslims to reformulate their classical kalam views which were apologetic to be the kalam of the dialogical and inclusive views because in the globalized framework or paradigm, Muslims have become directly or indirectly global citizens or global citizenship. Here is the challenge of religious communities today, Muslims must be able to dialogue 'an unchanging religion' with 'changing social dynamics'. Thus, the Islamic ummah must shift the paradigm to find religious conceptions that can answer the challenges of changing times and changing interpretations of the people of the times. This is not done by changing religious texts, but by articulating the religious spirit inherent in the narratives of the times.

This idea can be based on two things; The first is the systematization of the classical kalam that has long colored or influenced Islamic thought, when the emergence of new anomalies in religious life, it becomes imperative to reform and cleanse the kalam discourse from an exclusive and sectarian argument model because the method is no longer relevant to be developed in the era of multiculturalism. The second is the kalam dogmatic-abstract discourse must be rethought and reformulated. The Muslim theologians or the mutakallimun are required to include the praxis dimension as an update in the kalam studies. The praxis dimension referred to as the kalam must cover various contemporary human problems such as the issue of religious pluralism, multiculturalism crisis, poverty problem, corruption problem, and others.

Social theology emphasizes the importance of dialogue and tolerance, not debate that is argumentative ad hominin, looking to win and lose, to show superiority and sectarianism. We think that the classical kalam methods and thinking modes cannot contribute to the modern and contemporary human civilization. The classical kalam contains the notion of pure and pristine religious dogmas contradicting the religious deviated dogmas. The nature of religious texts in the Holy Quran does not change. However, the interpretation and articulation of the text in the Holy Quran are dynamic because humans live in an ever-changing social reality. With this perspective, the religious adherents need to stop their religious thoughts and practices leading to the claims of truths without opening the doors to the reasoning and reflective aspects or elements found in their respective religions.

To realize and develop social theology, awareness of the importance of objectification is needed. When society is increasingly plural, especially in the space of the nation-state, then Muslims must accept pluralism as a logical consequence of national life. The journey of life of Muslims in their religion must not only be dominated by the kalam and fiqh interpretations which are stagnant, but it is also important to involve the experience of religious praxis in the reality of multi-cultural societies. Consequently, some religious practices in the form of interaction, in which Muslims must do good to fellow human beings as a manifestation of "faith and" pious deeds "so that it is with empirical experiences that make reasoning in religion dynamic.

According to the authors of this article, the 'dialogical' religious sense is indeed analogized with a "theological social" paradigm needed to be developed in the context of interfaith and intrareligious relations; such as Muslim-Christian relations in the context of the state of Indonesia. Among the Muslims themselves, they have to establish the good relation and communication among Muslim sects such as the Sunnites, the Shiites and 0ther relations-Shiiin minority groups such as Ahmadiyah, Bahai, Sunda Wiwitan and others. Sometimes, Muslim-Christian problems 
are too far dragged to certain practical political interests (politicization of religion), and the same can happen the politization of religion realted to the Sunnite and Shiite problems.

To conclude, the proposal of the reconstructed kalam as a science of Islam is expected to be grounded and based on the new paradigm shift in line with the present and contemporary problems and challenges confronting or challenging the globalized Muslims and their current conditions. This proposal is also supported by the Islamic principles as found in the teachings of Islam related to the rahmatan li al-'alamin and the ummatan wasatan which are useful also beneficial for Muslims themselves as well as for non-Muslims. The main step to undertake this "big project" is related to our joint intention in giving a birth to the reconstructed kalam model requiring a new container in the kalam fields. This new container is an extension of our joint efforts that will seek a reconstruction of the kalam as we wish and plan. We are all involved in this big kalam project, at least in delivering suggestions, which in our opinions must be at the level of legal dictum known as the individual obligation or responsibility and its Arabic term is the fardu 'ain.

Hopefully, this is a good and wonderful dream of the Department of Philosophy and Religion of Paramadina University Jakarta and the Islamic Studies and the Faculty of Ushuluddin in IAIN and UIN, which we must support together. If we do not answer wisely to the negative views on the usefulness and importance of the past kalam that existed during the classical and medieval periods of Muslim history and civilization, the past or ancient kalam most likely will be suspended from Muslim colleges and universities and Islamic studies in Indonesia. Whereas the kalam as an Islamic science in its new paradigm covering some new topics and methods is very crucial and fundamental in Islam. The reconstructed kalam and its importance and significance are for the guidance of Muslim and human life contributing directly or indirectly to a progressive and peaceful community of multi-religious adherents leading to the formation of a progressive and peaceful government for all Indonesians.

\section{References}

Abduh, Muhammad. 1366 H. Risalat al-Tawhid. Cairo: Dar al-Manar. Abdullah, Amin. 1995. Falsafah Kalam di Era Postmodernisme. Yogyakarta: Pustaka Pelajar. al-Ahwani, Ahmad Fu'ad. 1962. al-Falsafat al-Islamiyyat. Cairo: al-Ta'rif al-Tarjamah wa al-Nasyr. Amin, Ahmad. 1936. Dhuha al-Islam. Vol. III. Cairo: Maktabat al-Nahdat.

Amuli, Jawadi. 2011. Keindahan \& Keagungan Perempuan: Perspektif Studi Perempuan dalam Kajian Al-Qur'an, Filsafat dan Irfan. Translated by Mudhor Ahmad. Jakarta: Sadra Press.

Azizi, A. Qadri. 2003. Pengembangan Ilmu-Ilmu Keislaman. Jakarta: Dirjen Pendis.

Basyir, Himat. 2012. Tafsir al-Muyassar. Translated by Izzudin Karimi. Solo: An-Naba'. Dahlan, Abdul Aziz. 2001. Teologi dan Akidah dalam Islam. Padang: IAIN-Press.

Hamka. 2003. Tafsir Azhar. Singapore: Kerjaya Printing Industries Pte. Ltd.

Ibn Khaldun. 1981. Muqaddimah al-Allamah Ibn Khaldun. Vol I. Beirut: Dar al-Fikr.

Imani, Kamal Faqih. 2003. Tafsir Nurul Qur'an, Terj (Nur al-Qur'an: An Enlightening Commentary into the Light of Holy Qur'an). Jakarta: Al-Huda.

Kathir, Ibn. 1419 H. Tafsir al-Qur'an al-'Adhim. Juz. I. Beirut: Dar al-Kutub al-'Ilmiah.

Kuntowijoyo. 2006. Islam Sebagai Ilmu. Yogyakarta: Tiara Wacana.

Kuntowijoyo. 2008. Paradigma Islam. Bandung: Mizan.

al-Mahalli, Jalaluddin \& Al-Suyuthi, Jalaluddin. 1416 H. Tafsir Jalalain. Beirut: Muassisah al-Nur Lilmatbu'at.

Madjid, Nurcholish. 1990. Reaktualisasi Nilai-Nilai Kultural dan Spiritual dalam Proses Transformasi Masyarakat: Masalah Penyajian Kembali Islam Sebagai Sumber Keinsafan Makna Hidup di Indonesia Modern. Paper of National Symposium of Muslim Scholar, Malang. 6-8 Desember. 
Misrawi, Zuhairi 2007. Al-Qur'an dan Toleransi: Inklusivisme, Pluralisme, Multikutralisme. Jakarta: Penerbit Fitrah.

Nasution, Harun. 1972. Teologi Islam. Jakarta: Universitas Indonesia.

Nasution, Harun. 1989. Falsafat Islam. Paper of Islamic Philosophyafter Ibn Rushd. Yayasan Muthahari/Lembaga Studi Agama dan Filsafat (LSAF). Jakarta 12-13 August.

al-Qurtubiy. 1993. Al-Jami' li Ahkam al-Qur'an. Vol. I. Beirut: Dar al-Kutub al-'Ilmiyyah.

al-Razi, Fakhr al-Din. 1420 H. Tafsir Mafatih Al-Ghaib. Juz 4. Beirut: Dar al-Ihya' al-Turats al'Arabi.

Sugiharto, Bambang. 1996. Postmodernisme Tantangan bagi Filsafat. Yogyakarta: Kanisius.

al-Ṭabari. 1992. Tafsir Al-Tabari al-Musamma Jami' al-Bayan fi Ta'wil al-Qur'an. Vol. 2. Beirut: Lubnan. Dar al-Kutub al-'Ilmiyyah.

Yusuf, Yunan. 1990. Corak Pemikiran Kalam Tafsir al-Azhar. Jakarta: Panjimas.

Zar, Sirajuddin. 1996. Islam dan Kepemimpinan di Indonesia. al-Turas. (9). Oktober 1995-Januari 1996.

Zar, Sirajuddin. 1996. Rasionalisme dan Tradisionalisme dalam Berijtihad serta Implikasinya terhadap Perubahan Zaman. Paper of Regional Seminar of Faculty of Syari'ah Padang. 